\title{
Concentration of heavy metals and metalloids in the bottom sediments of the Vilkitsky Island's lakes (the Kara Sea)
}

\author{
Elena Agbalyan, Aleksander Krasnenko, and Elena Shinkaruk* \\ Arctic Research Center of the Yamal-Nenets autonomous district, 629000 Salekhard, Russia
}

\begin{abstract}
We performed this study in order to obtain relevant data about the actual ecological status of the lakes in remote areas of the Russian Arctic. The objective was to determine the level of technogenic pollution of bottom sediments in the lakes on the Vilkitsky island in the Kara Sea. To this end, we examined 8 of the island's small lakes. The content of heavy metals and metalloids ( $\mathrm{Ti}, \mathrm{V}, \mathrm{Cr}, \mathrm{Mn}, \mathrm{Fe}, \mathrm{Co}, \mathrm{Ni}, \mathrm{Cu}, \mathrm{Zn}, \mathrm{Ga}, \mathrm{As}, \mathrm{Y}$, $\mathrm{Nb}$ ) in the samples of bottom sediments was determined using the method of Energy Dispersive X-ray Fluorescence (EDXRF). The total pollution value in the examined bottom sediments varied from $\mathrm{Zc}=9.5$ to $\mathrm{Zc}=15.3$. The maximum level of pollution was found in Lake 4 located in an anthropogenically disturbed area due to the levels of $\mathrm{Cr}, \mathrm{Co}, \mathrm{Ni}, \mathrm{As}, \mathrm{Y}, \mathrm{Nb}$.
\end{abstract}

\section{Introduction}

Vilkitsky Island lies in the eastern part of the Kara Sea in the Arctic zone of the Russian Federation. The components of its natural environment have a substantial record of being used in human activity. Today the island's northeast coast features a functioning polar station as well as a number of abandoned military objects. The anthropogenic impact is associated with mechanical disturbance and chemical pollution of the area's surface soils. The sources of soil pollution are contained in solid natural and industrial waste. Works are currently in progress to clear and restore the island's anthropogenically disturbed areas [1, [2].

The hydrographic pattern of the island is represented by thermokarst lakes, pits, swamps and streams flowing from them, which form estuary coastland closer to the sea. The island has unique wetlands of the West Siberian Arctic island tundras and is a breeding ground for water fowl [2].

Our team assessed the ecological condition of the Vilkitsky Island's water bodies. Bottom sediments are an integral indicator of anthropogenic load on water bodies. Accumulating pollutants from the aquatic environment, they act as a potential source of secondary pollution.

We studied eight lakes located in the northeastern and southeastern parts of Vilkitsky Island, performing a thorough assessment of the granulometric and chemical composition

* Corresponding author: elena1608197@yandex.ru 
of bottom sediments employing the sieve method. The $\mathrm{pH}$ value of the aqueous extract of bottom sediments was determined with the use of the potentiometric method, and electrical conductivity (SEC), with the use of the conductometric method.

The aim of the work was to study the level of technogenic pollution of bottom sediments of the lakes of Vilkitsky Island.

\section{Materials and methods}

We studied eight lakes and one stream located in the northeastern and southeastern parts of Vilkitsky Island, performing a thorough assessment of the granulometric and chemical composition of bottom sediments employing the sieve method. The $\mathrm{pH}$ value of the aqueous extract of bottom sediments was determined with the use of the potentiometric method, and electrical conductivity (SEC), with the use of the conductometric method.

The content of heavy metals and metalloids (Ti, V, Cr, Mn, Fe, Co, Ni, Cu, Zn, Ga, As, $\mathrm{Y}, \mathrm{Nb}$ ) was determined by X-ray fluorescence energy dispersive analysis (XPAED) using a BRA 135-f spectrometer (NPP NPO JSC Petrel, Saint Petersburg). We conducted these studies using the chemical analytical laboratory of the Nadym State Scientific Institute of Yamalo-Nenets Autonomous District's Scientific Center for Arctic Studies.

To assess the pollution levels of bottom sediments, we used the background values obtained for the tundra region of the Yamalo-Nenets Autonomous District that are presented in a study by T. Kremlyova (2015).

We assessed pollution levels in bottom sediments using the Kc concentration factors and the total pollution index, Zc. The concentration coefficient characterizes the amount of bottom sediment elements relative to their background levels. Our calculations include elements with Kc values of at least 1.5. The total pollution value is the sum of the concentration coefficients of the corresponding elements; it reflects the additional excess of the background level and characterizes the level of technogenic pollution.

\section{Results}

The granulometric composition is an important characteristics of bottom sediments. The ability of bottom sediments to concentrate and retain trace elements depends on the particle size. Due to the large surface area, fine-grained bottom sediments are the main places where inorganic and organic components accumulate [4].

The granulometric composition of the bottom sediments of the examined lakes varied within a small range of values, from $<0.1 \mathrm{~mm}$ to $1 \mathrm{~mm}$, with the sand fraction prevailing in all of the bottom sediment samples.

The sample collection point on Lake No. 1 shows, primarily, the accumulation of medium $(70.0 \%)$ and fine $(26.4 \%)$ sands; the share of fractions smaller than $0.1 \mathrm{~mm}$ is $2.8 \%$. The maximum content of thin sands and silty sands was found in the bottom sediments of Lake No. 3 and unnamed lake No. 4 (6.6\% and 4.9\%, respectively). Lake No 2 shows the biggest amount of small sand fractions $(0.1-0.25 \mathrm{~mm})$ amounting to $11.6 \%$ in the bottom sediments, whereas Lake No. 3 shows the amount of $18.4 \%$, and Lake No. 4 the amount of $20.4 \%$.

The gross composition of lake sediments corresponds to the genesis of the rocks of the catchment basin (deposits of laidas, watten, sea shores). Bottom sediments B-01, B-02, B03 and B-04 show a more pronounced ability to accumulate trace elements.

The $\mathrm{pH}$ values of water extracts of bottom sediments ranged from $6.33 \mathrm{pH}$ units to 6.74 $\mathrm{pH}$ units. The reaction of the environment of bottom sediments was slightly acidic. 
A high variability of UEP values was found in the bottom sediment water extracts (from $10.5 \mu \mathrm{S} / \mathrm{cm}$ to $280.2 \mu \mathrm{S} / \mathrm{cm}$ ). In two of the examined lakes, a significant content of basic ions was found in the water extracts of the bottom sediments.

We noted a significantly wide range of variation in the concentrations of heavy metals in the bottom sediments (Table 1). $\mathrm{Zn}$ and $\mathrm{Cu}$ were detected in one of the B-04 samples $(20.8 \mathrm{mg} / \mathrm{kg}$ and $1.4 \mathrm{mg} / \mathrm{kg}$, respectively), which had been taken in an anthropogenically disturbed area. The content of heavy metals in the remaining samples of the bottom sediments was within the detection limits. Ni was detected in samples B-03 and B-04 in quantities of $1.5 \mathrm{mg} / \mathrm{kg}$ and $25.5 \mathrm{mg} / \mathrm{kg}$, respectively. The concentration of $\mathrm{Ni}$ in the bottom sediments of Lake No. 4 exceeds the background value by 1.8 times.

Table 1. Content of heavy metals and As in the bottom sediments of the lakes of Vilkitsky Island $(\mathrm{mg} / \mathrm{kg}$ )

\begin{tabular}{|c|c|c|c|c|c|c|}
\hline Water body & Code & $\mathrm{Cr}$ & $\mathrm{Ni}$ & $\mathrm{Cu}$ & $\mathrm{Zn}$ & As \\
\hline Unnamed lake No. 1 & B-01 & 49.9 & BLD & BLD & BLD & 23.5 \\
\hline Unnamed lake No. 2 & B-02 & 48.4 & BLD & BLD & BLD & 25.85 \\
\hline Unnamed lake No. 3 & B-03 & 61.8 & 1.5 & BLD & BLD & 24.3 \\
\hline Unnamed lake No. 4 & B-04 & 97.0 & 25.5 & 1.4 & 20.8 & 20.4 \\
\hline Unnamed lake No. 5 & B-05 & 34.6 & BLD & BLD & BLD & 24.1 \\
\hline Unnamed lake No. 6 & B-06 & 48.7 & BLD & BLD & BLD & 28.6 \\
\hline Unnamed lake No. 7 & B-07 & 64.5 & BLD & BLD & BLD & 26.7 \\
\hline Unnamed lake No. 8 & B-08 & 47.9 & BLD & BLD & BLD & 28.4 \\
\hline Stream 1 & B-p1 & 31.6 & BLD & BLD & BLD & 24.8 \\
\hline Stream 2 & B-p2 & 45.6 & BLD & BLD & BLD & 27.2 \\
\hline \multicolumn{2}{|l|}{$\mathrm{M} \pm \mathrm{SD}$} & $53.0 \pm 16.7$ & $13.5 \pm 9.8$ & - & - & $25.4 \pm 2.3$ \\
\hline \multicolumn{2}{|c|}{ Tundra zone background* } & 37.8 & 14.2 & 9.4 & 29.8 & 2.9 \\
\hline \multicolumn{2}{|l|}{ Clark** } & 83 & 58 & 47 & 83 & 17 \\
\hline
\end{tabular}

Note: BLD - below detection limit, * - background values (as per [3]), ** clarks of the elements in the earth's crust (as per [5])

The content of As in the bottom sediments varies from $20.4 \mathrm{mg} / \mathrm{kg}$ in the sample B-04 to $28.6 \mathrm{mg} / \mathrm{kg}$ in the sample B-06. The concentrations of As in all samples are higher than the background value.

The average content of $\mathrm{Cr}$ in the bottom sediments is $53.0 \pm 16.7 \mathrm{mg} / \mathrm{kg}$. The concentration of $\mathrm{Cr}$ varies from $31.6 \mathrm{mg} / \mathrm{kg}$ in the sample B-p1 to $97 \mathrm{mg} / \mathrm{kg}$ in the sample $\mathrm{B}-04$. The content of $\mathrm{Cr}$ exceeds the background $\mathrm{Cr}$ level by 2 times in the sample and B-04 and by 1.3 times in the samples B-03 and B-07.

The content of $\mathrm{Ti}$ in the samples of the bottom sediments B-01, B-02, B-03, B-04 exceeds the background value (Table 2). The maximum concentration of $\mathrm{Ti}$ was found in the sample B-04, whereas the minimum content of this element was registered for the sample B-p1.

The $\mathrm{V}$ concentrations in the bottom sediments vary widely from $0.2 \mathrm{mg} / \mathrm{kg}$ to 53.8 $\mathrm{mg} / \mathrm{kg}$. The maximum $\mathrm{V}$ content was found in the sample B-04. The V contents in the bottom sediments of Lakes No. 1, 3, 4 and 6 are above the background level.

The average concentrations of $\mathrm{Mn}$ and $\mathrm{Fe}$ in the bottom sediments are $275.3 \pm 98 \mathrm{mg} / \mathrm{kg}$ and $8854.7 \pm 8144.6 \mathrm{mg} / \mathrm{kg}$, respectively. The maximum concentration of $\mathrm{Mn}$ was found in the samples B-07 (453.3 mg/kg) and B-04 (390.8 mg/kg). The maximum content of Fe was 
registered for the in sample B-04. The content of $\mathrm{Mn}$ and Fe in the bottom sediments of Lakes No. 3, No. 4 and No. 6 is higher than the background values.

Table 2. Content of heavy metals in the bottom sediments of the lakes of Vilkitsky Island ( $\mathrm{mg} / \mathrm{kg}$ )

\begin{tabular}{|c|c|c|c|c|c|c|c|c|c|}
\hline Water body & Code & $\mathrm{Ti}$ & V & $\mathrm{Mn}$ & $\mathrm{Fe}$ & $\mathrm{Co}$ & $\mathrm{Ga}$ & Y & $\mathrm{Nb}$ \\
\hline $\begin{array}{c}\text { Unnamed lake } \\
\text { No. } 1\end{array}$ & B-01 & $3,417.1$ & 11.6 & 332.6 & $8,742.3$ & BLD & 5.02 & 12.1 & 10.2 \\
\hline $\begin{array}{l}\text { Unnamed lake } \\
\text { No. } 2\end{array}$ & B-02 & $5,861.1$ & 2.6 & 223.7 & BLD & BLD & 3.85 & 9.9 & 14.3 \\
\hline $\begin{array}{c}\text { Unnamed lake } \\
\text { No. } 3\end{array}$ & B-03 & $4,315.7$ & 16.5 & 331.0 & $11,472.1$ & 2.23 & 5.24 & 12.7 & 14.6 \\
\hline $\begin{array}{c}\text { Unnamed lake } \\
\text { No. } 4\end{array}$ & B-04 & $6,558.9$ & 53.8 & 390.8 & $27,519.9$ & 9.90 & 7.36 & 19.7 & 16.8 \\
\hline $\begin{array}{l}\text { Unnamed lake } \\
\text { No. } 5\end{array}$ & B-05 & 858.3 & BLD & 107.5 & $1,016.0$ & BLD & 1.85 & 7.5 & 14.7 \\
\hline $\begin{array}{c}\text { Unnamed lake } \\
\text { No. } 6\end{array}$ & B-06 & $2,397.6$ & 23.8 & 330.4 & $20,870.3$ & BLD & 3.53 & 9.1 & 13.1 \\
\hline $\begin{array}{c}\text { Unnamed lake } \\
\text { No. } 7\end{array}$ & B-07 & $2,726.3$ & 5.6 & 453.3 & 7301.5 & 0.97 & 5.62 & 13.4 & 19.9 \\
\hline $\begin{array}{c}\text { Unnamed lake } \\
\text { No. } 8\end{array}$ & B-08 & $1,752.0$ & BLD & 168.8 & 6158.2 & 0.57 & 1.63 & 8.7 & 14.5 \\
\hline Stream 1 & B-p1 & 184.5 & BLD & 181.4 & $1,064.4$ & BLD & 2.23 & 7.6 & 14.3 \\
\hline Stream 2 & B-p2 & $2,448.9$ & 0.2 & 233.0 & $4,402.8$ & BLD & 3.01 & 10.0 & 17.5 \\
\hline \multicolumn{2}{|l|}{$\mathrm{M} \pm \mathrm{SD}$} & $\begin{array}{c}3,052.1 \\
\pm \\
1,847.4\end{array}$ & $\begin{array}{c}11.4 \pm \\
15.4\end{array}$ & $\begin{array}{c}275.3 \\
\pm \\
98.7\end{array}$ & $\begin{array}{c}8,854.7 \\
\pm \\
8,144.6\end{array}$ & $\begin{array}{c}25.4 \pm \\
2.3\end{array}$ & $\begin{array}{c}3.9 \pm \\
1.7\end{array}$ & $\begin{array}{l}11.1 \\
\pm 3,3\end{array}$ & $\begin{array}{c}15.0 \pm \\
2,4\end{array}$ \\
\hline \multicolumn{2}{|c|}{$\begin{array}{l}\text { Tundra zone } \\
\text { background* }\end{array}$} & 6,000 & 51.9 & 460 & 20,600 & 2.9 & 7.2 & 11,4 & 7,5 \\
\hline \multicolumn{2}{|l|}{ Clark** } & ,500 & 90 & 1,000 & 46,500 & 17 & 19 & 29 & 20 \\
\hline
\end{tabular}

Note: BLD - below detection limit, * - background values (as per [3]), ** clarks of the elements in the earth's crust (as per [5])

The content of Co in the bottom sediments of Lakes No. 1, No. 2, No. 5 and No. 6 and the stream are below the detection limit. In other water bodies, the Co concentrations differed by 17 times (samples B-08 and B-04) and 4.4 times (samples B-03 and B-04). The maximum Co concentration was registered for the bottom sediments of Lake No. 4 (9.9 $\mathrm{mg} / \mathrm{kg})$.

The concentration of $\mathrm{Ga}$ in the bottom sediments of the examined lakes varies from 1.63 $\mathrm{mg} / \mathrm{kg}$ to $7.36 \mathrm{mg} / \mathrm{kg}$. The maximum concentration of $\mathrm{Ga}$ was registered for the bottom sediments of Lake No 4, and the minimum concentration was detected in Lake No 8. The bottom sediments of Lakes No. 1, 2, 3, 4 and 7 showed increased concentrations of Ga in relation to the background value.

The average content of $Y$ in the bottom sediments is $11.1 \pm 3.3 \mathrm{mg} / \mathrm{kg}$. The maximum concentration of $Y$ was registered for the bottom sediments of Lake No. $4(19.7 \mathrm{mg} / \mathrm{kg})$, and the minimum concentration of $7.5 \mathrm{mg} / \mathrm{kg}$ is observed in Lake No. 5. The bottom sediments of Lakes No. 1, 3, 4 and 7 showed a content of Y exceeding the background value.

The content of $\mathrm{Nb}$ in the bottom sediments of the lakes varies insignificantly from 10.2 $\mathrm{mg} / \mathrm{kg}$ to $19.9 \mathrm{mg} / \mathrm{kg}$. The maximum concentrations of $\mathrm{Nb}$ were registered for the bottom sediments of Lakes No. 7 and No. 4. The average Nb content in the bottom sediments is 
$15.0 \pm 2.4 \mathrm{mg} / \mathrm{kg}$. The background $\mathrm{Nb}$ content in the bottom sediments of the lakes of the tundra zone of the Yamalo-Nenets Autonomous District is two times lower [3].

The calculated concentration coefficients relative to the baseline values showed an increased content of As (KAs from 7.0 to 9.8), Cr (KCro№№3 = 1.6; KCroz№4 = 2.6; KCroz№7 = 1.7), Ni (KNioz№ $4=1.8)$ and Y (KYoz№4 = 1.7) in the bottom sediments (Table 3). The total pollution value in the bottom sediments was found to vary from $\mathrm{Zc}=$ 9.5 to $\mathrm{Zc}=15.3$. The average pollution level was established for all of the examined water bodies, with the exception of Lake 1. The highest level of pollution was found in Lake 4, located in the anthropogenically disturbed area, due to the accumulations of $\mathrm{Cr}, \mathrm{Co}, \mathrm{Ni}, \mathrm{As}$, $\mathrm{Y}$, and $\mathrm{Nb}$ there.

Table 3. Concentration coefficients and total pollution value of the bottom sediments on Vilkitsky Island.

\begin{tabular}{|c|c|c|c|c|c|c|c|c|c|c|c|c|c|c|}
\hline Code & $\mathrm{Ti}$ & $\mathrm{V}$ & $\mathrm{Cr}$ & $\mathrm{Mn}$ & $\mathrm{Fe}$ & $\mathrm{Co}$ & $\mathrm{Ni}$ & $\mathrm{Cu}$ & $\mathrm{Zn}$ & $\mathrm{Ga}$ & $\mathrm{As}$ & $\mathrm{Y}$ & $\mathrm{Nb}$ & $\mathbf{Z c}$ \\
\hline B-01 & 0.6 & 0.2 & 1.3 & 0.7 & 0.4 & 0.0 & 0.0 & 0.0 & 0.0 & 0.7 & 8.1 & 1.1 & 1.4 & $\mathbf{9 5}$ \\
\hline B-02 & 1.0 & 0.0 & 1.3 & 0.5 & 0.0 & 0.0 & 0.0 & 0.0 & 0.0 & 0.5 & 8.9 & 0.9 & 1.9 & $\mathbf{1 0 . 8}$ \\
\hline B-03 & 0.7 & 0.3 & 1.6 & 0.7 & 0.6 & 03 & 0.1 & 0.0 & 0.0 & 0.7 & 8.4 & 1.1 & 1.9 & $\mathbf{1 1 9}$ \\
\hline B-04 & 1.1 & 1.0 & 2.6 & 0.8 & 1.3 & 1.5 & 1.8 & 0.2 & 0.7 & 1.0 & 7.0 & 1.7 & 2.2 & $\mathbf{1 5 3}$ \\
\hline B-05 & 0.1 & 0.0 & 0.9 & 0.2 & 0.0 & 0.0 & 0.0 & 0.0 & 0.0 & 0.3 & 83 & 0.7 & 2.0 & $\mathbf{1 0 3}$ \\
\hline B-06 & 0.4 & 0.5 & 1.3 & 0.7 & 1.0 & 0.0 & 0.0 & 0.0 & 0.0 & 0.5 & 9.8 & 0.8 & 1.7 & $\mathbf{1 1 5}$ \\
\hline B-07 & 0.5 & 0.1 & 1.7 & 1.0 & 0.4 & 0.1 & 0.0 & 0.0 & 0.0 & 0.8 & 9.2 & 1.2 & 2.7 & $\mathbf{1 2 . 6}$ \\
\hline B-08 & 0.3 & 0.0 & 1.3 & 0.4 & 0.3 & 0.1 & 0.0 & 0.0 & 0.0 & 0.2 & 9.8 & 0.8 & 1.9 & $\mathbf{1 1 . 7}$ \\
\hline B-p1 & 0.0 & 0.0 & 0.8 & 0.4 & 0.1 & 0.0 & 0.0 & 0.0 & 0.0 & 0.3 & 8.6 & 0.7 & 1.9 & $\mathbf{1 0 5}$ \\
\hline B-p2 & 0.4 & 0.0 & 1.2 & 0.5 & 0.2 & 0.0 & 0.0 & 0.0 & 0.0 & 0.4 & 9.4 & 0.9 & 2.3 & $\mathbf{1 1 . 7}$ \\
\hline
\end{tabular}

\section{Discussion}

There are no regulatory documents establishing the levels of maximum allowable concentrations of heavy metals in bottom sediments. There is information about regional standards approved by the Order of the Department of Natural Resources Regulation, Forestry Affairs and Development of the Oil and Gas Industry of the Yamalo-Nenets Autonomous District dated 27 March 2017 No. 348 “On Establishing Environmental Quality Standards" Background Contaminants in Snow Cover, Surface Sediments of Water Bodies and Vegetation within the territory of the Yamalo-Nenets Autonomous District." Comparison of the measured concentrations of the elements in the bottom sediments of the water bodies of Vilkitsky Island with the values established by the environmental quality standard reveals an increase in the content of Mn in Lake No. 7.

The 2017 studies of Vilkitsky Island showed that most of the water bodies situated within the anthropogenic zone are moderately polluted. The water body located on the border of a military unit and an industrial waste landfill can be classified as polluted [2]. Furthermore, our data indicate the average degree of pollution of most of the examined lakes.

The bottom sediments of the lakes of Vilkitsky Island are As-rich. According to some authors, the soils of the Yamal-Nenets Autonomous District are characterized by an increased content of As, which indicates an increased regional background value [6].

Increased concentrations of $\mathrm{Mn}$ in the surface waters of the Autonomous District are typical of that area and have to do with the geochemical features of the territory [7]. Mn enters the 
environment in the process of chemical weathering of rocks and minerals, and has a high mobility in wetlands [8].

\section{Conclusion}

The island of Vilkitsky in the Kara Sea is currently uninhabited, with its natural landscapes previously disturbed by human activity.

The analysis of the ecological condition of the Vilkitsky Island water bodies was carried out on the basis of geochemical criteria for the pollution of bottom sediments. The bottom sediments of the examined lakes are represented by sand fractions. The environment of bottom sediments has demonstrated a slightly acidic reaction; we have also observed and confirmed UEP variability in the water extracts of bottom sediments.

In accordance with the total contamination value, the average pollution value for each of the examined lakes (except one) has been determined on base of the extreme As concentrations that are naturally conditioned. The most extreme pollution levels have been found in the lake located in the area that's home to the abandoned military objects.

As of today, works to clean the island of Vilkitsky are underway. In the years ahead, reclamation of the disturbed and contaminated land will be mandatory.

The research was supported by the Non-Commercial Partnership "Russian Center of Arctic Exploration".

\section{References}

1. R.A. Kolesnikov, V.M. Makeev, E.N. Romanova, E.V. Rozhkovsky, R.D. Vostrikov, Science Bulletin of the Yamalo-Nenets Autonomous Okrug, 3(96), 11-19 (2017).

2. R.A. Kolesnikov, V.M. Makeev, E.N. Romanova, V.I. Sturman, K.A. Zhurkina, Engineering survey. 12(5-6), 32-41 (2018)

3. T.A. Kremleva, Geochemical factors of resistance of water systems to anthropogenic loads: Dissertation, 260 (Moscow, 2015)

4. V.A. Dauvalter, Geoecology of bottom sediments of lakes, 224 (MSTU Publishing House, Moscow, 2012)

5. A.P. Vinogradov, Geochemistry, 7, 555-571 (1962)

6. V.M. Tomashunas, E.V. Abakumov, Hygiene and Sanitation, 93(6), 26-31 (2014).

7. E.V. Agbalyan, E.V. Shinkaruk, Successes of the Modern Natural Science, 7, 45-51 (2019)

8. T.I. Moiseenko, G.V. Kalabin, V.Y. Khoroshavin, Bulletin of the RAS. Geographical series, 2, 49-58 (2012) 